\title{
ガスクロマトグラフィーによる排水中のトリブチルスズ及び トリフェニルスズ化合物の定量
}

\author{
服部幸和 ${ }^{\circledR}$, 山本仁史, 永井寛治, 野中和代, \\ 橋本浩一, 中村 智, 中本雅雄 ${ }^{*}$, 安念 清, \\ 坂森重治 ${ }^{* *}$, 白石寛明, 森田昌敏 ${ }^{* * *}$
}

(1990 年 6 月 4 日受理)

\begin{abstract}
内標準物質として塩化トリペンチルスズを用いて, 排水中におけるトリブチルスズ及びトリフェニル スズ化合物（TBT, TPT) の定量法を検討した。水試料を塩酸酸性下でへキサンにより抽出し, 濃縮後, グリニヤール試薬を用いてプロピル化し，フロリジルカートリッジカラムを通してクリーンアップを行 い, 炎光光度検出器付き GC（GC-FPD）（スズ用フィルター付き）を用いて定量した。本法による TBT 及び TPT の検出限界はそれぞれ $10 \mathrm{ng} / 1,30 \mathrm{ng} / 1$ (塩化物換算) であり, 本法を造船, 塗料及び 製薬業の排水試料の分析に適用し，ガスクロマトグラム上の妨害ピークもなく良好な結果が得られた. 添加回収試験の回収率は，96〜104\%，105〜106\%，相対標準偏差はそれぞれ $2.2 \sim 6.8 \% ， 1.8 〜 7.3 \%$ であった。 又, GC/MS を用いる測定についても検討した結果, GC-FPD による測定值とよく一致した。 更に，標準溶液及び排水試料の测定における相対標準偏差は，それぞれ $2.0 \sim 2.7 \%, 1.3 \sim 1.7 \%$ と良好 であり，実排水試料の分析にも適用可能であった。
\end{abstract}

\section{1 緒馬}

トリブチルスズ化合物（TBT）及びトリフェニルス ズ化合物（TPT）は, 船底塗料や漁網防污剤のほか農 薬としても使用されており，比較的毒性の強い化合物で ある. 最近, これらの有機スズ化合物（OTC）による 魚介類, 底質及び水質の污染がクローズアップされ, 魚 類による生物モニタリング調査や環境調査が行われ, 環 境污染の実態が明らかにされつつある1)2).

それに伴い,ビス(トリブチルスズ)オキシド(TBTO) が “化学物質の審査及び製造等の規制に関する法律 (化審法)”に基づく“第一種特定化学物質”に指定され たのをはじめ3), 多くの TBT 及び TPT が “第二種特定 化学物質” 又は “指定化学物質” に指定され, 污染の拡 大の防止に努力が払われている.

OTCの分析方法については多くの報告がある が4) 11), 最近, GC-FPDにより測定する方法が広く用

* 大阪府公害監視セン夕ー : 537 大阪府大阪市東成区 中道 1-3-62

** 富山県公害センター : 939-03 富山県射水郡小杉町中 太閤山

*** 環境庁国立環境研究所 : 305 茨城県つくば市小野川 16-3
いられている.しかし，現在，広く環境調査に用いられ ている分析方法は, 前処理として非常に煩雑な操作と熟 練技術を要し，測定精度や回収率の点で問題がある．従 って, 再現性が高くはん用性のある分析方法が公定法と して望まれている.

本報告においては, 従来の分析法より簡便な前処理法 を採用し, 又内標準物質 (surrogate compound) として 塩化トリペンチルスズ $\left(\mathrm{Pe}_{3} \mathrm{SnCl}\right)$ を用いた $\mathrm{GC}-\mathrm{FPD}$ による定量法を開発した。更に本法の各種排水試料への 適用性を検討した。 又 GC/MSによる測定法について も検討した。

\section{2 実験}

\section{$2 \cdot 1$ 試薬及び装置}

ヘキサン, メ夕ノール, エタノール, 酢酸エチル, ジ エチルエーテル : 和光純薬工業製残留農薬試験用

水: イオン交換後蒸留した水

臭化プロピルマグネシウム $(2 \mathrm{~mol} / \mathrm{l}$, テトラヒドロ フラン溶液) : 東京化成工業製

硫酸, 塩酸 : 有害金属測定用

塩化ナトリウム: 和光純薬工業製特級試薬

無水硫酸ナトリウム: 和光純薬工業製残留農薬試験用 
塩化トリブチルスズ $\left(\mathrm{Bu}_{3} \mathrm{SnCl}\right)$ : 東京化成工業製試 薬一級

塩化トリフェニルスズ $\left(\mathrm{Ph}_{3} \mathrm{SnCl}\right)$ : 東京化成工業製 試薬特級

塩化トリペンチルスズ $\left(\mathrm{Pe}_{3} \mathrm{SnCl}\right)$ 標準原液 : 国立環 境研究所において合成した $100 \mathrm{ppm}$ エ夕ノール溶液,

以下, トリペンチルスズ化合物を TPeT と略記

塩化トリブチルスズ標準原液 : エタノール溶液

塩化トリフェニルスズ標準原液: 酢酸エチル: エ夕 ノール $(1: 1)$ 溶液

有機スズ混合溶液 (ヘキサン溶液) : $\mathrm{Bu}_{3} \mathrm{SnCl}(1$ $\mathrm{mg} / \mathrm{l}), \quad \mathrm{Ph}_{3} \mathrm{SnCl}(3 \mathrm{mg} / \mathrm{l}), \mathrm{Pe}_{3} \mathrm{SnCl}(1 \mathrm{mg} / \mathrm{l})$ の混合 標準溶液を作製して使用した。

添加用内標準溶液 : $\mathrm{Pe}_{3} \mathrm{SnCl}$ 標準原液をへキサンで希 釈して適当な濃度 $(0.1 \mathrm{mg} / \mathrm{l})$ のものを作製して使用し た。

絶対検量線法用標準溶液: 有機スズ混合標準溶液 $0.2,0.4,0.6,0.8,1.0 \mathrm{ml}$ をとりへキサンで $1 \mathrm{ml}$ とし た. 次に, 臭化プロピルマグネシウム溶液 $1 \mathrm{ml}$ を加え てプロピル化を行い, $0.5 \mathrm{M}$ 硫酸 $10 \mathrm{ml}$, メタノール 10 $\mathrm{ml}$ 及び蒸留水 $10 \mathrm{ml}$ を加えて処理した後, ヘキサン 2 $\mathrm{ml}$ で 2 回抽出して, 合わせて $5 \mathrm{ml}$ 定容とした.

内標準法用混合標準溶液: $\mathrm{Bu}_{3} \mathrm{SnCl} \quad 0.05 \sim 5.0 \mu \mathrm{g}$ ( $\mathrm{Ph}_{3} \mathrm{SnCl}$ は $\mathrm{Bu}_{3} \mathrm{SnCl}$ の 3 倍量) を含む量を段階的に とり, それぞれに $\mathrm{Pe}_{3} \mathrm{SnCl} 0.5 \mu \mathrm{g}$ を加えたへキサン溶 液を同様にプロピル化して作製した。

TBT, TPT 及び TPeT の量はすべて塩素化物換算值 とする.

フロリジルカートリッジカラム : ウォーターズ製セッ プパックフロリジルカートリッジ

\section{$2 \cdot 2$ 装}

ガスクロマトグラフ : 島津製作所製 GC-9AM に同社 製 FPD（有機スズ用フィルター付き）及びスプリット レス注入口を装備させたものを使用.

GC/MS : ヒューレットパッカード製 HP5890 型ガス クロマトグラフに同社製質量選択検出器 (MSD) HP5970 型を装備したものを使用.

\section{$2 \cdot 3$ 分析操作}

水試料 11 を分液漏斗に量りとり, 適当量の内標準 液, 濃塩酸 $10 \mathrm{ml}$ 及び塩化ナトリウム $20 \mathrm{~g}$ を加え, へ キサン $100 \mathrm{ml}$ を加えて振り混ぜて抽出した後, ヘキサ ン相が十分に分離するまで静置した. 水相を別の分液漏 斗に移し, 水相に再びへキサン $100 \mathrm{ml}$ を加えて同様に
抽出を行い，分離したへキサン相を合わせた。合わせた ヘキサン相を無水硫酸ナトリウムを加えて脱水し, 沪過 した後, ロータリーエバポレーターを用いて $40^{\circ} \mathrm{C}$ 以下 で, 約 $5 \mathrm{ml}$ まで減圧濃縮し, 濃縮液を共栓付き試験管 $25 \mathrm{ml}$ に移しドライヤーにより穏やかに加熱しながら窒 素を吹き付けて約 $1 \mathrm{ml}$ まで濃縮して, プロピル化用試 料液とした. プロピル化用試料液に臭化プロピルマグネ シウム溶液 $1 \mathrm{ml}$ を加えて軽く振り混ぜ, 室温において 30 分間放置した. $0.5 \mathrm{M}$ 硫酸 $10 \mathrm{ml}$ を水冷しながら 徐々に加えて, 分液漏斗 $100 \mathrm{ml}$ に移し, メ夕ノール 10 $\mathrm{ml}$ 及び水 $10 \mathrm{ml}$ でそれぞれ分液漏斗に洗い込んだ。分 液漏斗に $5(\mathrm{v} / \mathrm{v}) \%$ エーテルーヘキサン混液を $2.5 \mathrm{ml}$ ず つ加えて 2 回抽出した. 有機溶媒相を水 $10 \mathrm{ml}$ で 2 回 軽く洗浄した後, 小漏斗に脱脂綿又は石英ウールで栓を して，その上に載せた無水硫酸ナトリウムを通して脱水 してカラム処理用試験液とした。フロリジルカートリッ ジカラムにヘキサン $10 \mathrm{ml}$ を通して洗浄した後, カラ ム処理用試験液を添加した。 $5(\mathrm{v} / \mathrm{v}) \%$ エーテルーヘキ

Table 1 GC-FPD conditions

\begin{tabular}{ll}
\hline Column & $\begin{array}{c}\text { DB-l }(0.53 \mathrm{~mm} \text { i.d. } \times 30 \mathrm{~m}, \\
\text { film thickness } 1.5 \mu \mathrm{m})\end{array}$ \\
Carrier gas & $\mathrm{He}(20 \mathrm{ml} / \mathrm{min})$, \\
Make up gas & $\mathrm{He}(20 \mathrm{ml} / \mathrm{min})$, \\
Column temperature & $80^{\circ} \mathrm{C}(1 \mathrm{~min})$, \\
& $80^{\circ} \mathrm{C} \sim 160^{\circ} \mathrm{C}\left(40^{\circ} \mathrm{C} / \mathrm{min}\right)$, \\
& $160^{\circ} \mathrm{C} \sim 290^{\circ} \mathrm{C}\left(10^{\circ} \mathrm{C} / \mathrm{min}\right)$, \\
& $290^{\circ} \mathrm{C}(3 \mathrm{~min})$, \\
Detector & $\mathrm{FPD}(\mathrm{Sn}-\mathrm{filter})$ \\
& $\mathrm{H}_{2}=200 \mathrm{ml} / \mathrm{min}$, \\
& air $=40 \mathrm{ml} / \mathrm{min}$ \\
Injector temperature & $290^{\circ} \mathrm{C}$ \\
Detector temperature & $300^{\circ} \mathrm{C}$ \\
\hline
\end{tabular}

Table 2 GC/MS conditions

\begin{tabular}{ll}
\hline Column & $\begin{array}{c}\text { DB-1 }(0.25 \mathrm{~mm} \text { i.d. } \times 30 \mathrm{~m}, \\
\text { film thickness } 0.25 \mu \mathrm{m})\end{array}$ \\
Carrier gas & $\mathrm{He}(1 \mathrm{ml} / \mathrm{min})$, \\
Column temperature & $60^{\circ} \mathrm{C}(2 \mathrm{~min})$, \\
& $60^{\circ} \mathrm{C} \sim 160^{\circ} \mathrm{C}\left(40^{\circ} \mathrm{C} / \mathrm{min}\right)$, \\
& $160^{\circ} \mathrm{C} \sim 260^{\circ} \mathrm{C}\left(10^{\circ} \mathrm{C} / \mathrm{min}\right)$, \\
& $260^{\circ} \mathrm{C}(16 \mathrm{~min})$, \\
Injection & auto injector \\
& splitless, purge off $1 \mathrm{~min}$ \\
Injector temperature & $260^{\circ} \mathrm{C}$ \\
Interface temperature & $270^{\circ} \mathrm{C}$ \\
Selected ion $(\mathrm{m} / \mathrm{z})$ & $\mathrm{TBT} 277 ; \mathrm{TPT} 351 ; \mathrm{TPeT} 303$ \\
Sample size & $2 \mu \mathrm{l}$ \\
\hline
\end{tabular}


サン混液で, $10 \mathrm{ml}$ の共栓付き試験管に溶出し溶出液量 を約 $10 \mathrm{ml}$ とした. 溶出液をドライヤーにより穏やか に加熱しながら窒素を吹き付けて $1 \mathrm{ml}$ まで濃縮して試 験液とした。

試験液の一定量（通常 $3 \mu \mathrm{l}$ ）をマイクロシリンジを用 いてとり，ガスクロマトグラフに注入し， TBT, TPeT, TPT のプロピル化物の保持時間に相当するピー クについて, ピーク高さを測定して, 内部標準法により 試料中の TBT 及び TPT の濃度 $(\mathrm{ng} / \mathrm{l})$ を算出した.

GC 及び GC/MS 測定条件を Table 1 及び 2 に示し た。

\section{3 結果及び考察}

\section{$3 \cdot 1$ 抽出・漕樎条件の検討}

5 種類の溶媒 (ベンゼン, ジクロロメタン, ジエチル

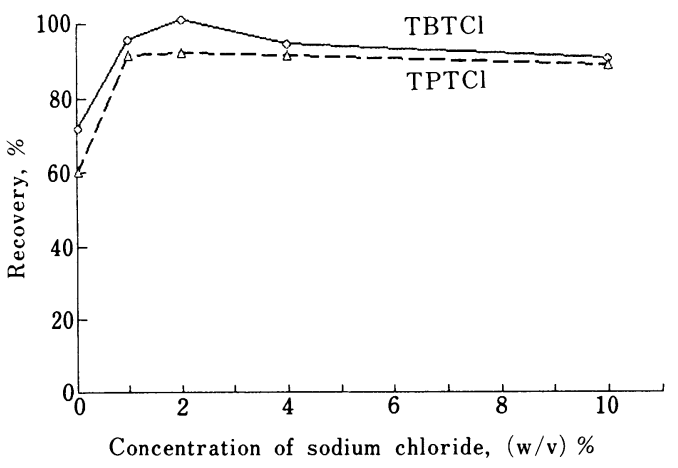

Fig. 1 Effect of concentration of sodium chloride on recovery of tributyltin chloride and triphenyltin chloride

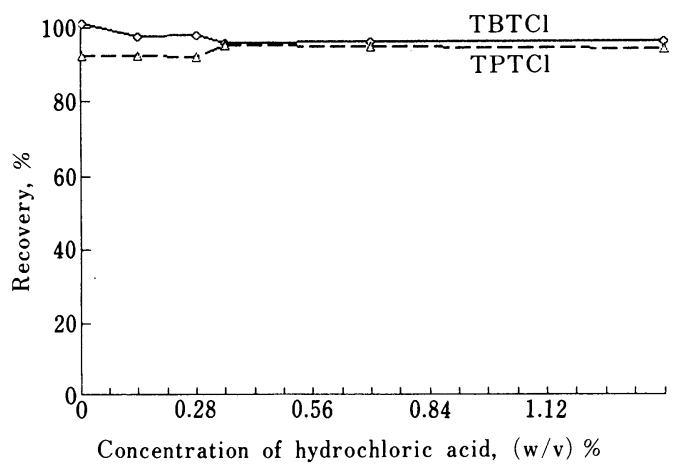

Fig. 2 Effect of concentration of hydrochloric acid on recovery of tributyltin chloride and triphenyltin chloride
エーテル, ヘキサン, 酢酸エチル) について酸及び塩類 を加えない条件で TBT 及び TPT の抽出率を調べた が，大きな差は見られなかった。 ベンゼン及びジクロロ メタンは毒性が強く作業環境上好ましくなく，酢酸エチ ルは，濃縮にも時間がかかるので，ヘキサンを抽出溶媒 として酸濃度及び塩類濃度の検討を行った。その結果を Fig. 1 及び 2 に示した. 水 11 に対し, 塩化ナトリウ 厶 $20 \mathrm{~g}$ 及び塩酸 $10 \mathrm{ml}$ を添加することとした.

又, 濃縮条件を検討した結果, 塩化物, プロピル化物 ともにロータリーエバポレーターによる減圧濃縮 $\left(40^{\circ} \mathrm{C}\right)$ 操作による損失はなかった，又，窒素吹き付け による濃縮も穏やかに加熱すればほとんど損失はなかっ た。

\section{$3 \cdot 2$ 誘導体化及び GC 分析}

OTC の誘導体化の方法としてプロピル化及び水素化 がよく用いられているが，GC 測定時の測定精度におい

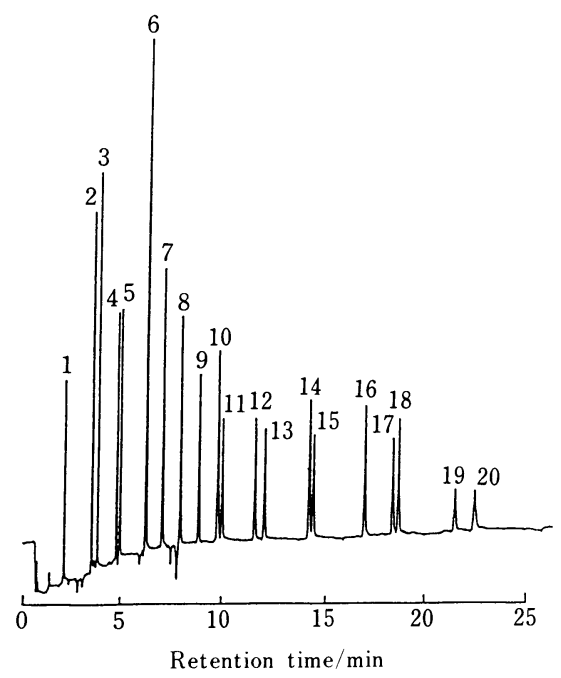

Fig. 3 Gas chromatogram of propyl derivatives of organotin compounds

Peaks - (1) trimethylpropyltin, (2) dimethyldipropyltin, (3) tetraethyltin, (4) methyltripropyltin, (5) diethyldipropyltin, (6) tetrapropyltin, (7) tripropylbutyltin, (8) dipropyldibutyltin, (9) propyltributyltin, (10) tetrabutyltin, (11) tripropylphenyltin, (12) tripropyloctyltin, (13) propyltripentyltin, (14) dipropyldiphenyltin, (15) dipropyldicyclohexyltin, (16) dipropyldioctyltin, (17) propyltriphenyltin, (18) propyltricyclohexyltin, (19) propyltrioctyltin, (20) tetraphenyltin. The amount of organotin compounds were about $2 \mathrm{ng}$, except that of tetrapropyltin was about $4 \mathrm{ng}$. 


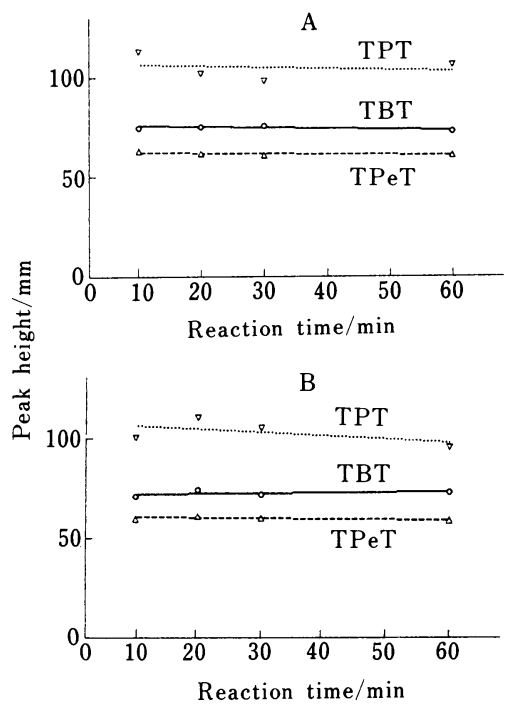

Fig. 4 Reaction time of propyl derivatives of tributyltin and triphenyltin

A : room temperature; $\mathrm{B}: 40^{\circ} \mathrm{C}$

てプロピル化物のほうが優れていたのでプロピル化によ り分析した．21 種の有機スズ化合物のガスクロマトグ ラムを Fig. 3 に示した。いずれも良好な分離が得られ た. 又, Fig. 4 に示したように, 室温及び $40^{\circ} \mathrm{C}$ で反応 所要時間を調べた結果, いずれも 10 分でほぼ一定に達 したため, 反応時間は 30 分, 反応温度は室温とするこ ととした.

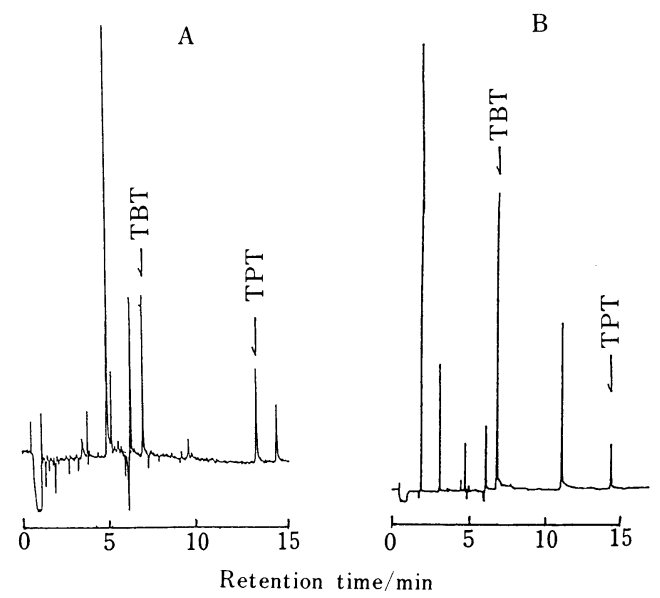

Fig. 5 Gaschromatograms of industrial waste water

A : ship building factory, B : paint industry

\section{$3 \cdot 3$ フロリジルカラム処理}

プロピル化した試料液をフロリジルカートリッジカラ ムを通してクリーンアップする方法を検討した。へキサ ンで溶出した場合, 回収率 70〜80\%であり, TPTを 溶出するのに $30 \mathrm{ml}$ を要した. $5(\mathrm{v} / \mathrm{v}) \%$ エーテルーへ キサン混夜で溶出させた場合, TBT, TPeT, TPT はす

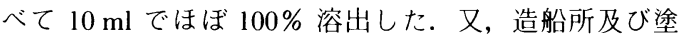
料工場の排水試料に本クリーンアップを用いた分析方法 を適用した結果, Fig. 5 に示すように, 良好なガスクロ マトグラムが得られ，妨害ピークは認められなかった。

\section{$3 \cdot 4$ 検量線}

$\mathrm{TBT} / \mathrm{TPeT}$ (濃度) 及び TPT/TPeT（濃度）を横軸 により,それぞれの応答の比を縦軸にとった内部標準用 検量線を Fig. 6 に示した. TBT/TPeT 及び TPT/ TPeT の值がそれぞれ $0.1 \sim 10$ 及び $0.3 \sim 30$ の範囲でそ れぞれの応答の比との直線性が確認された. 又, GC/MS の場合も TBT/TPeT 及び TPT/TPeT の值が それぞれ $0.1 \sim 10$ 及び $0.3 \sim 30$ の範囲でそれぞれの応答 の比との直線性が確認された。

\section{$3 \cdot 5$ 添加回収試検及び検出限界}

蒸留水及び排水 (造船所, 塗料工場, 製薬業) への添 加回収試験の結果を Table 3 に示した. TBT 及び TPT の回収率は，それぞれ 95.7〜104.3\%，105.4〜106.3\%， 相対標準偏差はそれぞれ 2.2 6.8\%，1.8～7.3\% と良好 な結果が得られた. なお, 塗料工場排水については, 添 加量に比較して無添加試料中の濃度が高かったので, 測 定值の相対標準偏差の值のみを示した。

本法による検出限界は, 水試料 11 から最終試験液量 $1 \mathrm{ml}$ まで濃縮するとすれば, TBT で $10 \mathrm{ng} / \mathrm{l}$, TPT で $30 \mathrm{ng} / \mathrm{l}$ であった。

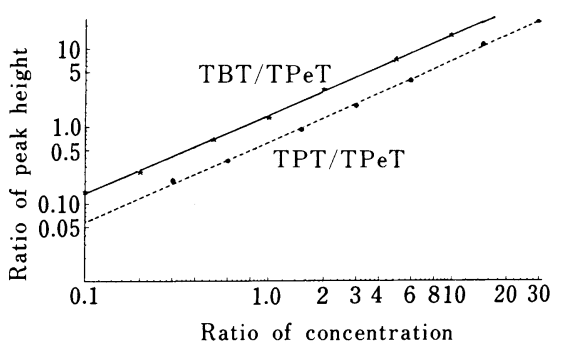

Fig. 6 Working curves of tributyltin and triphenyltin for internal standard method

TPeT : $500 \mathrm{ng}$ 
Table 3 Recovery of tributyltin (TBT) and triphenyltin (TPT) from distilled water and industrial waste water

\begin{tabular}{|c|c|c|c|c|c|}
\hline Sample & & Added/ng & Found \pm S.D. ${ }^{\text {a) }} / \mathrm{ng}$ & Recovery $^{\mathrm{b})}, \%$ & R.S.D. $^{\text {c) }}, \%$ \\
\hline \multirow[t]{4}{*}{ Distilled water } & TBT & 0 & N.D. ${ }^{d)}$ & & \\
\hline & & 100 & $95.7 \pm 4.9$ & 95.7 & 5.1 \\
\hline & TPT & 0 & N.D. ${ }^{d)}$ & & \\
\hline & & 300 & $319.0 \pm 19.2$ & 106.3 & 6.0 \\
\hline \multirow[t]{4}{*}{ Pharmaceutical factory } & TBT & 0 & N.D. ${ }^{\text {d) }}$ & & \\
\hline & & 100 & $103.9 \pm 2.2$ & 103.9 & 2.2 \\
\hline & TPT & 0 & N.D. ${ }^{\text {d) }}$ & & \\
\hline & & 300 & $316.4 \pm 9.0$ & 105.4 & 2.8 \\
\hline \multirow[t]{4}{*}{ Paints } & TBT & 0 & $189.5^{\mathrm{e})}$ & & \\
\hline & & 100 & $268.4 \pm 18.3$ & - & 6.8 \\
\hline & TPT & 0 & $108.0^{\mathrm{c})}$ & & \\
\hline & & 300 & $451.2 \pm 8.3$ & - & 1.8 \\
\hline \multirow[t]{4}{*}{ Ship building } & TBT & 0 & N.D. ${ }^{d)}$ & & \\
\hline & & 100 & $104.3 \pm 3.7$ & 104.3 & 3.5 \\
\hline & TPT & 0 & $34.0^{\mathrm{e})}$ & & \\
\hline & & 300 & $352.8 \pm 23.4$ & 106.3 & 7.3 \\
\hline
\end{tabular}

a) standard deviation; b) average of five runs ; c) relative standard deviation; d) not detected ; e) average of two runs

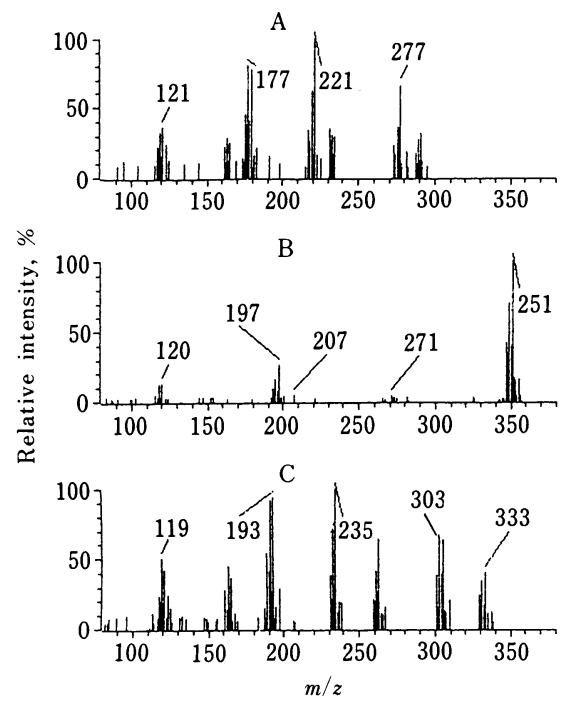

Fig. 7 Mass spectrum of propyl derivatives of tributylltin, triphenyltin and tripentyltin

A : tributyltin; B : triphenyltin; C : tripentyltin

\section{3・6 GC/MS による TBT，TPT の同定及び定量}

TBT, TPT 及び TPeT 標準溶液のマススペクトルを Fig. 7 に示した. $m / z 277$ (TBT), 351 (TPT), 303 ( TPeT) を設定質量数として, 選択イオン検出法 (SIM) による標準溶液及び排水試料液のクロマトグラ

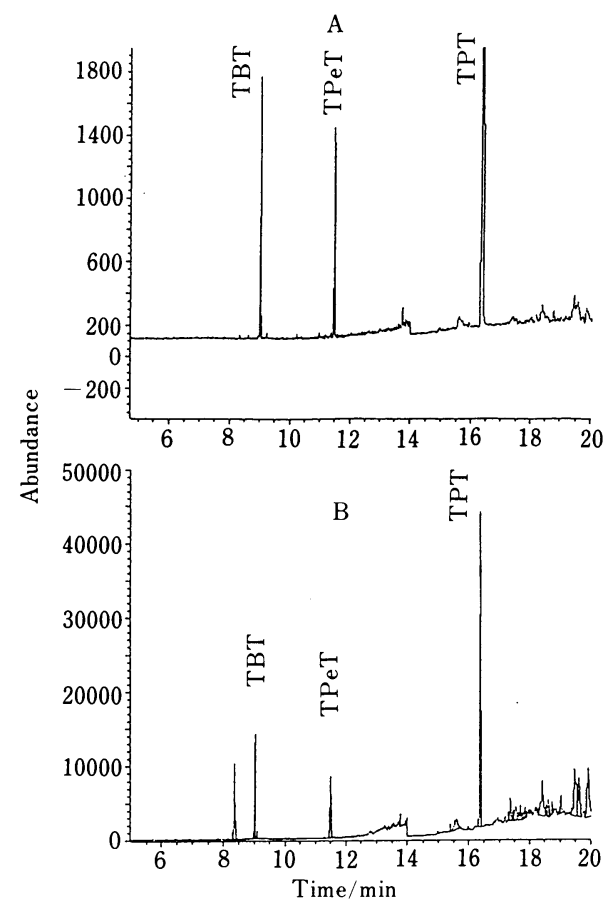

Fig. 8 Mass chromatograms of standard solution (A) and waste water from paint industry (B)

ムを Fig. 8 に示した. 排水試料液のマススペクトルに ついても標準溶液とよく一致し, TBT 及び TPT のプ 
ロピル化物であることが確認された．又，排水試料の定 量結果（ピーク面積により定量）はFPDによる定量値 とよく一致した。更に，標準溶液（TBT 40, 200 ng/l，TPeT 40，200 ng/l, TPT 120，600 ng/l）及び排 水試料の繰り返し測定精度は, それぞれ相対標準偏差で $0.4 \sim 1.7 \%, 1.1 \sim 2.5 \%, 1.1 \sim 3.7 \%$ と良好な結果を示し た. MS を用いた場合の検出限界は, $S / N=3$ として TBT で $4 \mathrm{pg}$, TPT で $3 \mathrm{pg}$ (Sn 換算でそれぞれ $2 \mathrm{pg}$, $1 \mathrm{pg}$ ) 程度であった。

\section{文献}

1) “昭和 63 年度版化学物質と環境”, 環境庁環境保 健部保健調查室.

2) “平成元年度版化学物質と環境”, 環境庁環境保健 部保健調査室.

3）官報号外第 183 号（平成元年 12 月 27 日）政令 第 351 号化学物質の審査及び製造等の規制に関
する法律施行令の一部を改正する政令.

4) Y. Arakawa, O. Wada, T. H. Yu and H. Iwai : J. Chromatogr., 216, 209 (1981).

5) Y. Hattori, A. Kobayashi, S. Takemoto, K. Takami, Y. Kuge, A. Sugimae : J. Chromatogr., 315, 341 (1984).

6) K. Takami, H. Yamamoto, T. Okumura, A. Sugimae, M. Nakamoto: Anal. Sci., 3, 165 (1987).

7) 昭和 63 年度化学物質分析法開発調査報告書, 環 境庁環境保健部保健調査室, p. 80.

8) J. J. Sullivan, J. D. Torkelson, M. W. Wekell, T. A. Hollingworth, W. L. Saxton, G. A. Miller, K. W. Panaro, A. Uhler: Anal. Chem., 60, 6260 (1988).

9) M. Muler: Anal. Chem., 59, 617 (1987).

10) K. Sasaki, T. Suzuki, Y. Saito : Bull. Environ. Contam. Toxicol., 41, 88 (1988).

11) D. J. Hannah, T. L. Page, L. Pickton, J. A. Taucher: Bull. Environ. Contam. Toxicol., 43, 22 (1989).

Determination of tributyltin and triphenyltin compounds in industrial waste water by GC. Yukikazu Hattori, Hitoshi Yamamoto, Kanji Nagai, Kazuyo Nonaka, Hirokazu Hashimoto, Satosi Nakamura, Masao Nakamoto*, Kiyoshi Annen, Shigeharu Sakamori $^{* *}$, Hiroaki Shiraishi and Masatoshi Morita ${ }^{* * *}$ ( ${ }^{*}$ Environmental Pollution Control Center, Osaka Prefectural Government, 1-3-62, Nakamichi, Higasinari-ku, Osaka-shi, Osaka 537; ${ }^{* *}$ Toyama Prefectural Environmental Pollution Research Center, Nakataikoyama, Kosugimachi, Imizu-gun, Toyama $939-03{ }^{* * *}$ National Institute for Environmental Studies, 16-2, Onogawa, Tsukuba-shi, Ibaragi 305)

Tributyltin (TBT) and triphenyltin compounds (TPT) in industrial waste water were determined by GC with flame photometric detector (FPD) using tripentyltin chloride $\left(\mathrm{Pe}_{3} \mathrm{SnCl}\right)$ as a surrogate compound. A volume of water sample $\left(\begin{array}{ll}1 & 1\end{array}\right)$ was mixed with 10 $\mathrm{ml}$ of hydrochloric acid and $20 \mathrm{~g}$ of sodium chloride and then extracted twice with $100 \mathrm{ml}$ of hexane. The extract was dehydrated with anhydrous sodium sulfate and concentrated to a small volume $(c a .5 \mathrm{ml})$ using a rotary evaporator. The concentrate was propylated with $1 \mathrm{ml}$ of $2 \mathrm{~mol} / \mathrm{l} n$-propylmagnesium bromide/tetrahydrofuran. Reaction product was passed through Sep-pak Florisil cartridge column and eluted with $5(\mathrm{v} / \mathrm{v}) \%$-diethylether/hexane. The eluate was concentrated to about $2 \mathrm{ml}$. Three microliters of the concentrate was analyzed by GC equipped with a capillary column $(0.53$ mm i.d. $\times 30 \mathrm{~m}$ ) coated with $1.5 \mu \mathrm{m}$ of DB-5 and FPD. TBT and TPT in industrial waste water from ship building, paint manufacture, and pharmaceutical factory were analyzed by this method. Recovery of TBT and TPT from these water samples was $96 \sim 104 \%, 105 \sim 106 \%$, respectively and the relative standard deviations (R.S.D.) were $2.2 \sim 6.8 \%, 1.8 \sim 7.3 \%$, respectively. The detection limits were $10 \mathrm{ng} / \mathrm{l}$ for TBT (as tributyltin chloride), $30 \mathrm{ng} / \mathrm{l}$ for TPT (as triphenyltin chloride). Analysis by GC/MS were also performed. Analytical data by GC/MS agreed well with the data by GC-FPD. R.S.D. by GC/MS were $0.4 \sim 1.7 \%$ for TBT, $1.1 \sim 2.5 \%$ for TPeT, $1.1 \sim 3.7 \%$ for TPT, when standard solution and actual waste water samples were analyzed.

(Received June 4, 1990) 


\section{Keyword phrases}

tributyltin and triphenyltin compounds; industrial waste water; tripentyltin chloride as surrogate compound; capillary GC-flame photometric detection and GC-MS; Florisil column; propylation with propylmagnesium bromide. 